
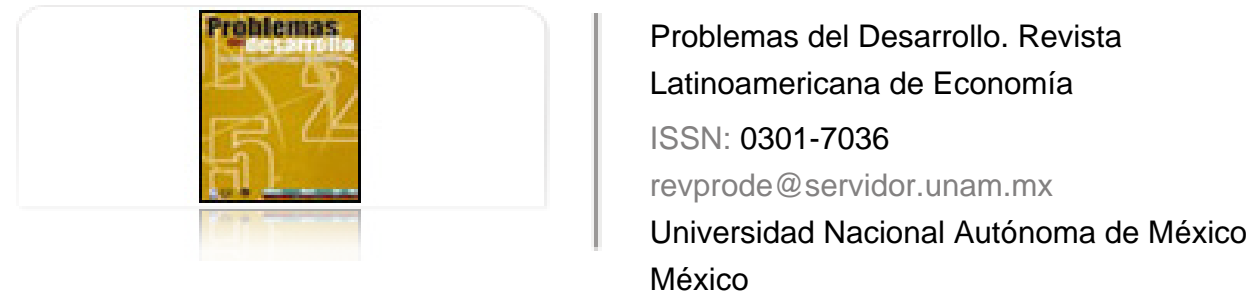

García, Clara

Capital inflows, policy responses, and their adverse effects: Thailand, Malaysia, and Indonesia in the decade before the crisis

Problemas del Desarrollo. Revista Latinoamericana de Economía, vol. 38, núm. 148, enero-marzo, 2007, pp. 9-39

Universidad Nacional Autónoma de México

Distrito Federal, México 


\section{CAPITAL INFLOWS, POLICY RESPONSES, AND THEIR ADVERSE EFFECTS: Thailand, Malaysia, AND INDONESIA IN THE DECADE BEFORE THE CRISES}

\section{Clara García*}

Fecha de recepción: 17 de agosto de 2006. Fecha de aceptación: 9 de diciembre de 2006.

\section{Abstract}

Capital inflows, especially when volatile and in foreign currencies, lead to macroeconomic and financial fragilities in the recipient economy. There is no consensus on which policies are best for tackling these problems. In this study, we try to find a unique criterion (a unifying lens) with which to assess the various policy alternatives for the cases where capital inflows - have been the result of stabilization and liberalization: the policies that might be most effective are those that depart from the stabilization and liberalization trend (1.e. capital controls, adjustments to currency regimes, or strengthened financial regulations). We support this idea with both theoretical arguments and case studies of Thailand, Malaysia, and Indonesia in the years prior to the 1997-1998 crises.

Key words: South East Asia, capital inflows, economic policy, financial fragility.

* Profesora adjunta, Universidad Complutense de Madrid. Correo electrónico: clara.garcia@ccee.ucm.es. Thanks: I am grateful to the Fundación Caja Madrid for its financial support, to Gerald Epstein and three anonymous referees for their useful comments and suggestions, and to Joseph Candora for his assistance. The usual disclaimer applies. 
Resumen

Las entradas de capital, especialmente cuando éste es de naturaleza volátil y en moneda extranjera, pueden acarrear fragilidades macroeconómicas y financieras en la economía receptora. No hay consenso en cuanto a qué políticas son las mejores para abordar tales problemas. En este trabajo tratamos de encontrar un único criterio o un mismo lente con el cual evaluar las diversas alternativas de política económica en los casos en que las entradas de capital han sido resultado de procesos de estabilización y liberalización: las políticas que podrían ser más eficaces serán aquellas que reviertan esa tendencia al ajuste y la liberalización (por ejemplo, controles de capital, ajustes en los regímenes cambiarios o regulaciones financieras más fuertes). Apoyamos esta idea con argumentos teóricos y con los estudios de caso de Tailandia, Malasia e Indonesia en los años previos a las crisis de 1997-1998.

Key words: Asia sudoriental, entradas de capital, politica económica, fragilidad financiera.

\section{Résumé}

Les entrées de capital, spécialement quand celui-ci est de nature volatile et en monnaie étrangère, peuvent entraîner des fragilités macro-économiques et financières dans l'économie réceptrice. Il n'y a pas consensus quant aux meilleures politiques face à de tels problèmes. Dans ce travail, nous tentons de trouver un critère ou une approche unique pour évaluer les diverses alternatives de politique économique dans les cas où les entrées de capital ont découlé de processus de stabilisation et de libéralisation: les politiques qui pourraient être les plus efficaces seront celles qui renversent cette tendance à l'ajustement et à la libéralisation (par exemple, contrôles de capital, ajustements dans les régimes de change ou plus fortes régulations financières). Nous défendons cette idée par des arguments théoriques et sur la base des études des cas de la Thaillande, de la Malaisie et de l'Indonésie dans les années antérieures aux crises de 1997-1998.

Mots clés: Asie du sud-est, entrées de capital, politique économique, fragilitéfinancière.

\section{Resumo}

As entradas de capital, especialmente cuando este é de natureza volátil e em moeda estrangeira, podem acarretar fragilidades macroeconômicas y financieras na economia receptora. Não há consenso sobre que políticas sejam as mejores para abordar tais problemas. Neste trabalho tentamos encontrar um único critério ou uma mesma lente com a qual avaliar as diversas alternativas de política econômica nos casos em que as entradas de capital tenham sido resultado de processos de estabilização e liberalização: as políticas que poderiam ser más eficazes seriam aquelas que revertessem essa tendência ao ajuste e à liberalização (por exemplo, controles de capital, ajustes nos regimes cambiais ou regulaciones financieras mais fortes). Apoiamos esta idéia com argumentos teóricos e com os estudos de caso da Tailândia, Malásia e Indonésia nos anos prévios às crises de 1997-1998.

Palavras chave: Ásia Sul-oriental, entradas de capital, política econômica, fragilidade financeira. 


\section{Introduction}

here is a growing consensus that a large quantity of capital inflows - especially when volatile, denominated in a foreign currency, and not properly hedged against exchange rate risks - may bring about overheating and financial risks (Montiel, 1995 and 1999; McKinnon and Pill, 1997; and Mishkin, 1998). However, there is no clear answer to the question of what is it that governments can do to prevent these adverse consequences. The question is one of great relevance, given that overheating and financial fragility have been systematically identified as the 'negative fundamentals' behind the financial crises of the 1990s in general, and behind the East Asian crises in particular. ${ }^{1}$

This paper argues that, when capital inflows are the consequence of stabilization and liberalization measures, ${ }^{2}$ policy options can be assessed under a unifying criterion: broadly speaking, the potentially most effective - though not necessarily the most used - policy actions are those which depart from previously taken stabilization and liberalization measures. Hence, as we shall argue, when capital inflows are being (promoted) by stabilization and liberalization, the response should not rely upon the use of restrictive demand policies and further trade and financial liberalization, but upon implementing inward capital controls, managing the nominal exchange rate, and strengthening financial regulation and supervision. However, as we shall also point out, the policies that are potentially most effective face important obstacles to their implementation, basically due to lack of support from the international financial community, or because they require institutional change. We support our arguments with theoretical reasoning, as well as with the case

1 On the links between loss of competitiveness and crises see Connolly and Taylor (1984) and Obstfeld (1994). On the relation between financial fragility and crises see Dooley (1997) and Chang and Velasco (1998). For the particular case of East Asia see Corsetti et al. (1998), IMF (1999), Krugman (1998), Wade (1998), World Bank (1998), and Bustelo et al. (2000).

2 This work does not try to prove that stabilization and liberalization measures caused the capital flows into Southeast Asia. It takes it as a premise, based on the conclusions of previous empirical testing. Although there is some theoretical and empirical support for push factors in explaining capital inflows (Sarno and Taylor, 1997; Fernandez Arias, 1996); Chuhan et al. (1993) and World Bank (1997) show how pull factors, mostly stabilization and liberalization, were especially determinant of capital flows into East Asia in the 1990s. 
studies of Thailand, Malaysia, and Indonesia (also, Asia-3) in the decade before the 1997 financial crises.

This work differs from the existing literature in two ways. First, it analyzes many of the options available to policymakers, instead of focusing on individual policy responses (examples of studies that concentrate on particular measures are Laban and Larrain, 1993; Calvo, 1990; and Llewellyn, 2000). Therefore, we offer a wide-ranging view of policymakers' options. Second, unlike the analyses that do review various policy options (Goldstein, 1995; Lee, 1996; Montiel, 1995 and 1999), this work does not enumerate the diverse pros and cons of each policy alternative. Instead, it contributes to the literature by trying to judge all policies at hand with one unifying criterion: whether they reinforce or depart from the measures that attracted capital in the first place. This criterion helps us to understand why certain policies may not be feasible and effective, or why certain others are not resorted to.

The paper is structured as follows. In section 2, we outline the mechanisms through which capital inflows bring about trade-related and financial problems, and we describe them for Asia-3. In section 3, we review the potential pros and cons of various policy responses with respect to capital inflows; and we show how policies that reinforce stabilization and liberalization risk being unfeasible, ineffective, or even counterproductive. Also, the cases of Asia-3 are presented. In section 4 , we summarize and conclude.

\section{Destabilizing effects of capital inflows}

Overheating and the deterioration of the current account balance

Overheating consists basically of the real appreciation of the domestic currency, which could ultimately lead to the weakening of the current account. Montiel (1995 and 1999) details the simple theoretical relationship between capital inflows and overheating. All else being equal, capital inflows, regardless of their composition, imply a surplus in the financial account. Under a fixed exchange rate regime, ${ }^{3}$ central bank intervention would bring about an accumulation of reserves. Given a simple equation of the central bank balance, $\mathrm{B}=\mathrm{R}+\mathrm{C}$ (where $\mathrm{B}$ is the monetary base, $\mathrm{R}$ the international reserves, and $\mathrm{C}$ the claims of the central bank to the public sector and the commercial banks), and holding $\mathrm{C}$ constant, more reserves lead to a higher monetary base. In turn, this implies a higher money supply, which brings

3 Because there were fixed exchange rate regimes in Thailand, Malaysia, and Indonesia (de facto or de iure), the argumentation will proceed under this assumption. 
about higher domestic demand and, ultimately, overheating and the deterioration of the current account.

All the elements of this theoretical causal chain were present in Asia-3. First, net capital inflows increased significantly starting in 1988, and particularly in the years closer to the 1997 financial crises (most notably in 1995). In Thailand, total net capital inflows (as reflected in the financial balance of the International Monetary Fund's International Financial Statistics, IFs hereafter) were 20 times higher in 1995 than in 1987 ( $\$ 1.1$ billion in 1987; \$21.9 billion in 1995). In Malaysia, they went from negative \$2 billion in 1988 to \$10.9 billion in 1997. And in Indonesia, capital inflows were almost five times higher in 1996 than in 1988 (\$2.2 billion in 1988; $\$ 10.8$ billion in 1996) (see Graph 1). There is some empirical evidence that these inflows were in part the consequence of stabilization and liberalization packages implemented mostly since the 1980s (Chuhan et al., 1993; World Bank, 1997).

Second, between 1988 and 1996, international reserves increased by 6.2 times in Thailand, 4.1 times in Malaysia, and 3.6 times in Indonesia (see Graph 2). This was because a considerable proportion of the net capital received was turned into reserves: $32 \%$ in Thailand, $43 \%$ in Malaysia, and 24\% in Indonesia (IFs data). Third, the monetary base ('reserve money' in the IFS) was significantly higher in 1996 than in 1988 in all three countries: 3.4 times in Thailand, 3.2 in Indonesia, and as much as 6.2 times in Malaysia (see Graph 3). As a percentage of GDP, the growth of the monetary base was lower but still considerable: in Thailand it grew from around $8 \%$ of GDP to $10 \%$; in Malaysia, from $12 \%$ to $27 \%$; and in Indonesia, from around $5 \%$ to almost $7 \%$. Fourth, M2 (the addition of 'money' and 'quasi-money' from the IFs) increased by around four times in all countries between 1988 and 1996 (see Graph 4). Relative to GDP, M2 growth was slower but still notable: in Thailand it jumped from 61\% in 1988 to $80 \%$ in 1996; in Malaysia from $65 \%$ to almost $92 \%$; and in Indonesia from $28 \%$ to $52 \%$. Fifth, domestic demand (private and public consumption and investment) also rose in the decade prior to 1997: 3.1 times in Thailand and Malaysia and 2.6 times in Indonesia between 1988 and 1996 (see Graph 5). Relative to GDP, domestic demand in Thailand grew from $99 \%$ of GDP in 1988 to $105 \%$ in 1996; in Malaysia it jumped from $89 \%$ to $98 \%$; and in Indonesia, it increased from $97 \%$ to $100 \%$. In all three cases, even higher rates were reached between 1991 and 1995.

As a result, inflation trended upward in the years when capital inflows and internal demand relative to GDP were growing, reaching maximums in 1990 and 1996 in 

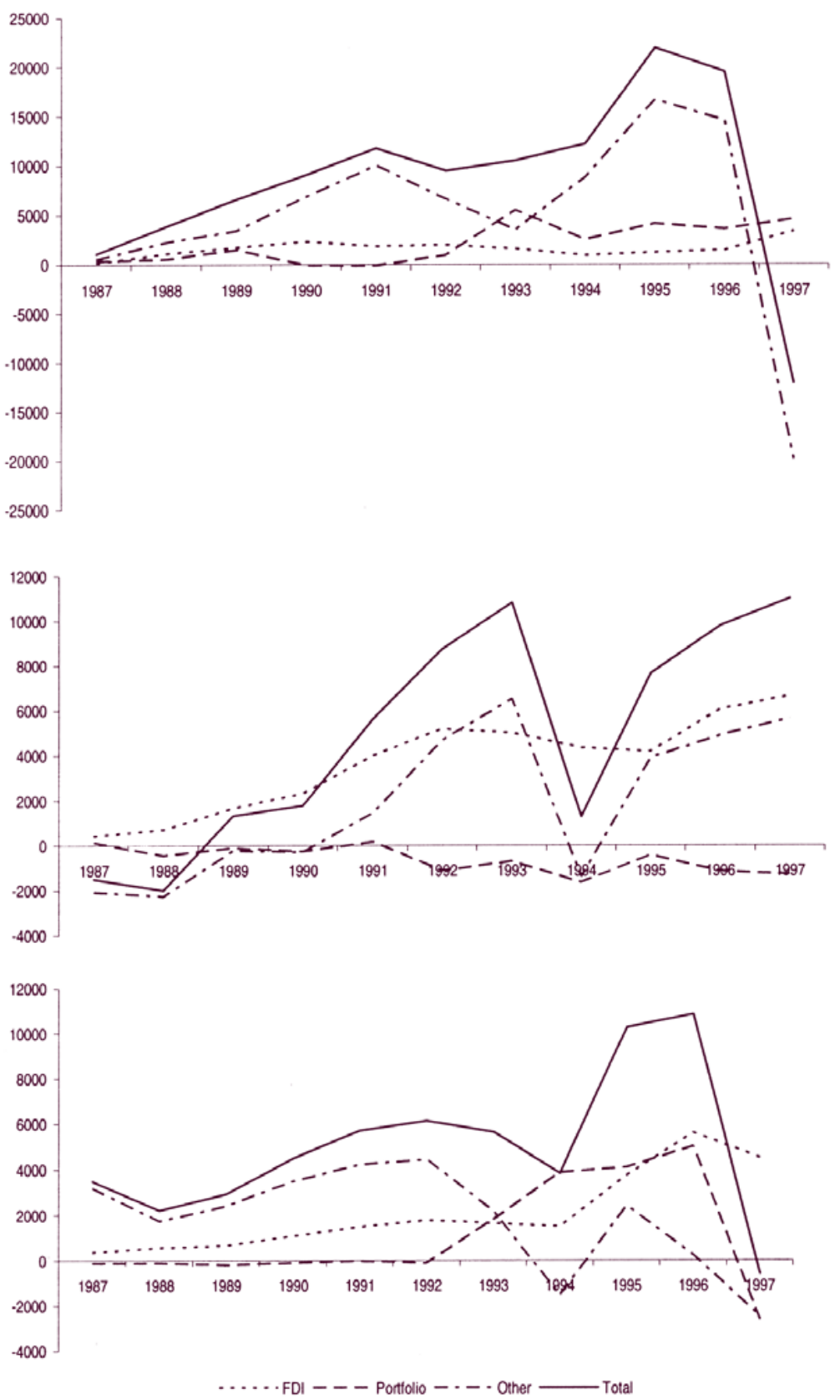

Graph 1. Capital inflows in Thailand, Malaysia and Indonesia (respectively), 1987-1997 (millions of dollars).

Source: International Financial Statistics (IMF). 


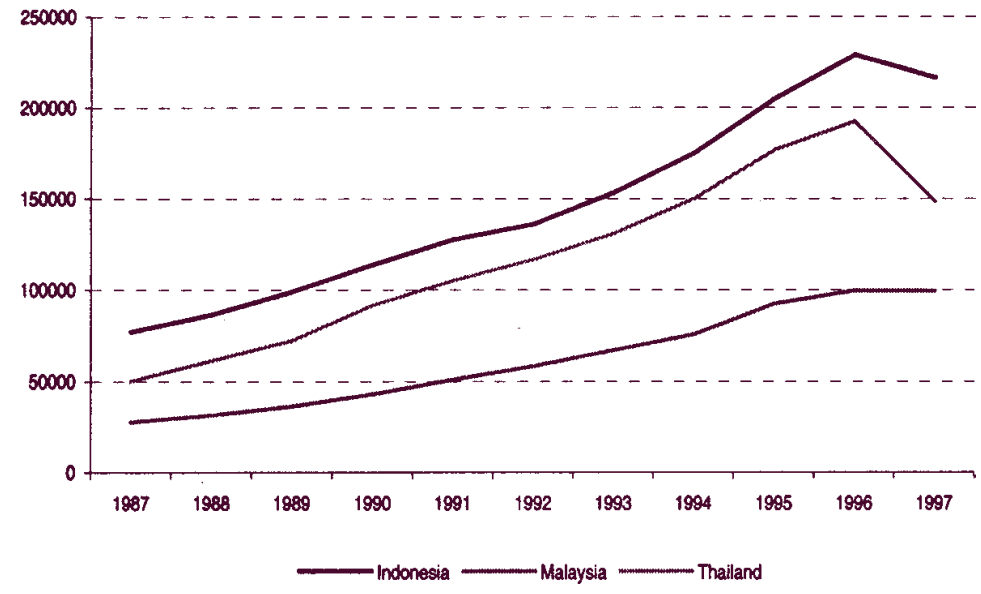

Graph 2. International reserves in Thailand, Malaysia and Indonesia, 1987-1997 (millions of dollars). Source: International Financial Statistics, IMF.

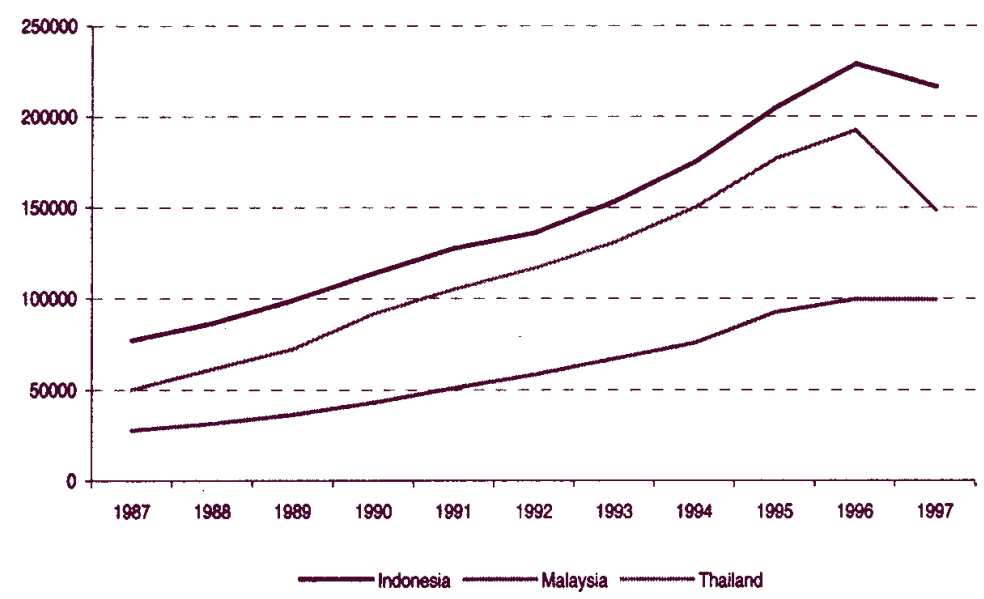

Graph 3. Monetary base in Thailand, Malaysia and Indonesia, 1987-1997 (millions of dollars). Source: International Financial Statistics, IMF.

Thailand (around 6\%), in 1992 and 1995 in Malaysia (about 5\%), and in 1991 and 1995 in Indonesia (around 9\%). Furthermore, the prices of certain assets, such as real estate and financial assets, rose most notably. There is still little agreement on how much the currencies of these countries appreciated in real terms; but that they did rise is not questioned. From December 1990 until March 1997, both the Thai 


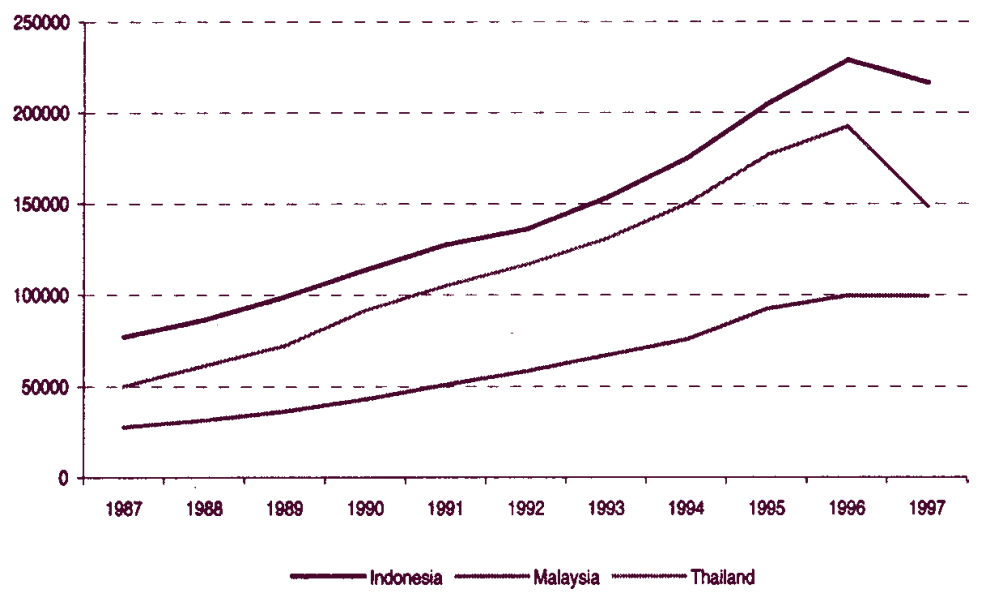

Graph 4. M2 in Thailand, Malaysia and Indonesia, 1987-1997 (millions of dollars) Source: International Financial Statistics, IMF; and author's calculations.

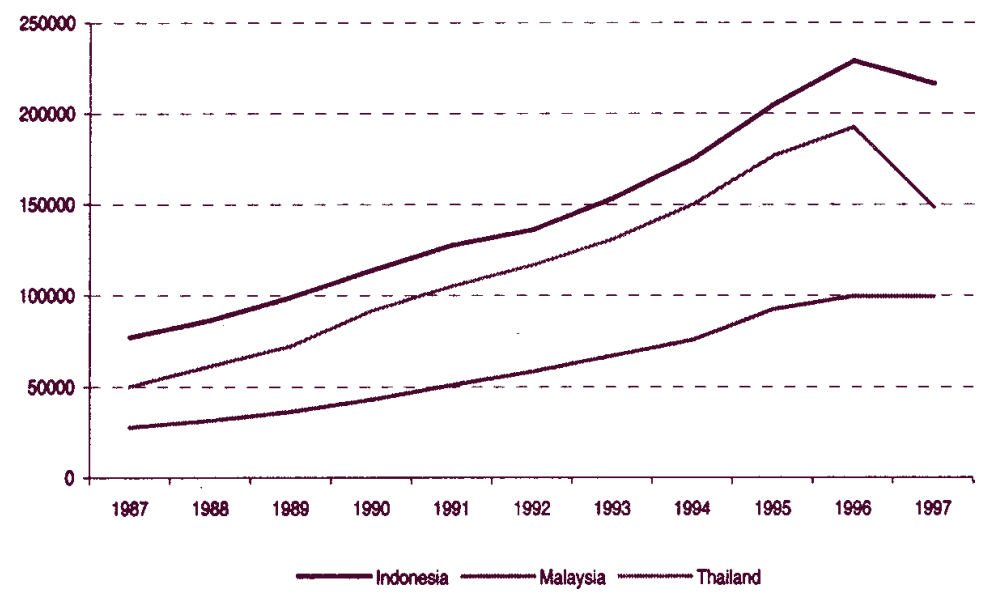

Graph 5. Domestic demand in Thailand, Malaysia and Indonesia, 1987-1997 (millions of dollars). Source: International Financial Statistics, IMF; and author's calculations.

baht and the Indonesian rupee experienced a real appreciation of about $25 \%$, while the Malaysian ringgit appreciated by $28 \%$ (Radelet and Sachs, 1998).

Finally, there was a deterioration of Asia-3 current account balances, which reached maximums in the years of particularly high growth or high levels of capital inflows. In Thailand, the current account deficit reached peaks in 1990-91 (about 
Table 1

Current account balance in Thailand, Malaysia, and Indonesia, 1987-1997 (\% of GDP) ${ }^{\mathrm{a}}$

\begin{tabular}{lrrrrrrrrrrr}
\hline & 1987 & 1988 & 1989 & 1990 & 1991 & 1992 & 1993 & 1994 & 1995 & 1996 & 1997 \\
\hline Thailand & -0.72 & -2.86 & -3.46 & -8.53 & -7.71 & -5.66 & -5.07 & -5.59 & -8.05 & -7.94 & -1.96 \\
Malaysia & 8.15 & 5.83 & 0.83 & -2.03 & -8.69 & -3.72 & -4.66 & -6.23 & -9.70 & -4.63 & -4.90 \\
Indonesia & -2.68 & -1.58 & -1.09 & -2.61 & -3.32 & -2.00 & -1.33 & -1.58 & -3.18 & -3.37 & -2.27 \\
\hline
\end{tabular}

a A negative sign indicates a deficit.

Source: International Financial Statistics (IMF); and author's calculations.

\$7.5 billion each year, or 8\% of GDP) and again in 1995-96 (around \$14 billion each year, also $8 \%$ of GDP). In Malaysia, current account surpluses turned into considerable deficits, particularly in 1991 (about $\$ 4$ billion, or $8.7 \%$ of GDP) and 1995 (around $\$ 8.5$ billion, or $9.7 \%$ of GDP). In Indonesia, the deterioration of the current account balance was lower, but it also peaked in periods of high capital inflows: in 1991 ( $\$ 4$ billion, or 3.3\% of GDP) and in 1996 ( $\$ 7.5$ billion, or also $3.3 \%$ of GDP) (see Table 1).

External factors contributed to these trade-related problems. Nevertheless, their impact was made possible by virtue of a stabilization and liberalization stance that was not modified in time. The real appreciation of the national currencies against the us dollar derived from rising inflation differentials, in turn the result not simply of the upward trend of domestic inflation, but also of a downward trend in us inflation (this was the case on 1991 and 1992, though not in 1995).

External factors also played a role in the real appreciation of the Asia-3 currencies. The appreciation of the dollar against other major currencies, between Spring 1995 and Summer 1997, fed the appreciation of the Asian currencies, which were pegged to the dollar. In any case, this could only happen by virtue of the fact that these countries did not resort to more flexible currencies.

The deterioration of the current account balance also owed something to external shocks. In 1994, the Chinese currency depreciated by about 50\%, although for the reasons exposed by Alba et al. (1998) the impact of the latter's currency depreciation was not very great. Also, the terms of trade of Asia-3 declined around 1996, mostly because of falling prices for certain microchips and other electronic components. Finally, in the years prior to the crises, industrialized countries went through a phase of lower import intensity, due to slow growth. In any case, these shocks could only operate by virtue of the progressive openness of the current account. 


\section{Financial fragility}

'Financial fragility' is here understood as the aggravation of financial risks. Domestic financial systems may suffer higher risks when they host not only domestic capital but also foreign capital. We now focus on three risks that are particularly sensitive to the inflow of capital: credit risks, market risks (in particular the exchange rate risk), and liquidity risks.

Credit risks arise from the over-intermediation of borrowed funds into excessive credit. As McKinnon and Pill (1997) and Mishkin (1998) argue, financial account openness and financial deregulation lead to excessive borrowing of foreign funds and their over-intermediation by the domestic financial system into a credit boom. This credit boom enhances the likelihood of default, given that the credit is directed toward high-risk activities. The circumstances which incite this risky lending might be (1) institutional guarantees (either explicit or implicit, either real or perceived); (2) uncertainty; and/or (3) the absence of a sound financial regulatory and supervisory system (Montiel and Reinhart, 2001; McKinnon and Pill, 1997).

A market risk that worsens in the context of liberalization and capital inflows is exchange rate risk. Banks are exposed to exchange rate risks when they are not adequately hedged, which is usually the case under the very circumstances that facilitate over-intermediation: institutional guarantees, uncertainty, and/or the absence of sufficient financial regulation and supervision. As Dooley (1999) argues, a fixed exchange rate works as an institutional guarantee and is therefore one of the possible causes for borrowers not protecting themselves from possible exchange rate movements.

Liquidity risks increase as a result of the maturity mismatch between assets and liabilities. Liquidity risks exist in the absence of capital inflows, given that transforming liquidities is precisely one of the functions of financial intermediation, but capital inflows enhance those risks by favoring financial over-intermediation.

In sum, for financial risks to increase, the composition of capital inflows matters as much as their quantity: capital inflows of a volatile nature imply a higher liquidity risk, while the denomination of inflows in foreign currencies brings with it a higher exchange rate risk.

Volatile capital is composed of both portfolio investment (PI) and short-term 'other investment' (OI), and this increased in Asia-3 in the years prior to 1997. The growth of foreign direct investment (FDI) flows into Thailand and Malaysia (but not Indonesia) started to decelerate around 1993. After that year, in Thailand and 
Indonesia, portfolio investments (PI) increased their presence both in absolute terms and as a proportion of the total inflow of capital. In Thailand and Malaysia, that which in the balance of payments appear as 'other investments' (OI) - mostly loans across countries - grew in absolute terms and as a share of total inflows in the early 1990s and again around 1995 (see Graph 1). Furthermore, foreign loans denominated in any currency and domestic loans in foreign currencies with a maturity of one year or less were a high proportion of total loans between the end of 1994 and the end of 1996: in Thailand, between 65\% and 74\%; in Malaysia, between $47 \%$ and 59\%, and in Indonesia between $60 \%$ and $62 \% .{ }^{4}$ In sum, volatile inflows rose in these countries, both in absolute terms and as a proportion of total capital inflows.

Finally, a high portion of the capital received was denominated in foreign currencies. Tang and Villafuerte (1995) show that in 1993, 80\% of the bonds issued in East Asian developing countries (Asia-3 among them) were denominated in dollars, and 16\% in yen. Also, the Bangkok International Banking Facility (BIBF) and the Labuan International Offshore Financial Center (IOFC) channeled foreign loans in foreign currencies (mostly dollars) into Thailand and Malaysia, respectively.

Capital inflows were intermediated into a credit boom, observable in the behavior of various parameters. First, M2, as a measure of liquidity, indicates whether foreign funds are being channeled into the domestic economy; and, as we have already seen, M2 grew, both in absolute terms and as a percentage of GDP. Second, the credit given by financial institutions increased: in Thailand, deposit banks' credit to private borrowers jumped from 64\% of GDP in 1990 to around 100\% in 1996; in Malaysia, from $71 \%$ to about $90 \%$; and in Indonesia, from $46 \%$ to more than $55 \%$ (IFS data). ${ }^{5}$

This credit was excessive because it was too risky: increasing proportions of the credit were extended for consumption or, more frequently, investment in real estate or securities: ${ }^{6}$ in Asia-3 between $25 \%$ and $40 \%$ of bank credit was channeled into real estate and securities in the years prior to the crises. The final symptom of overintermediation was, therefore, a price bubble in both the real estate and the securities

4 Data extracted from various years of The Maturity, Sectoral and Nationality Distribution of International Bank Lending, Bank for International Settlements (BIS).

5 These values are so much lower in Indonesia due to the fact that in this country non financial companies were the ones that borrowed more heavily from abroad. Therefore, in Indonesia, over intermediation did not happen through the financial system but directly through non financial corporations. Thus M2 is a more significant indicator in Indonesia than any measure of bank credit.

6 Analysts of the Bank of Thailand have acknowledged the links between capital inflows and a credit boom in the real estate and construction sectors for the Thai case (Disyatat et al., 2005). 
markets. Two other indicators also demonstrate the risks that domestic lending institutions were facing. First, the incremental capital output ratio (ICOR), which accounts for the efficiency of investment, grew from 1987-92 and 1993-96 in Thailand (3.4 and 5.1) and Malaysia (3.7 and 4.8), though not in Indonesia (4.0 and 3.8). ${ }^{7}$ Second, non-performing loans as a proportion of total lending in 1996 were 13\% in Thailand and Indonesia, and 10\% in Malaysia (Corsetti et al., 1998).

Regarding currency mismatches, we have already mentioned how a high proportion of bonds and loans were denominated in foreign currencies. At the same time, financial institutions and corporations channeled credit in national currencies. Furthermore, the increasing proportion of credit extended to real estate or stock market activities implied that a growing proportion of capital inflows was being lent to projects that could not generate foreign currency. Besides, there were incentives for exchange rate risk not to be hedged: high interest rate differentials combined with low exchange rate volatility could lead agents to believe that exchange rate risk was low (Eichengreen and Hausmann, 1999).

Finally, regarding liquidity risks, there was a maturity mismatch between the banks' assets and liabilities. As mentioned, volatile capital was an increasing proportion of total inflows. We have also shown that this capital was being channeled into investments that were unprofitable in the short term: real estate and securities, or else productive assets with long-term returns. Besides, the ratio of short-term debt to reserves, a habitual measure of liquidity risk, was $145 \%$ in Thailand and 170\% in Indonesia in June 1997 (only 61\% in Malaysia). Just as Indonesia suffered fewer trade-related problems, Malaysia faced lower exchange rate and liquidity risks, given its more cautious financial liberalization (García, 2005).

\section{Economic policy responses}

What were the choices for policymakers in these countries? Broadly speaking, any policies meant to limit the growth of M2 could serve the purpose of limiting both overheating and financial fragility, given the quasi-equivalence of $\mathrm{M} 2$ with domestic credit (the former refers to banks' liabilities and the latter to their assets). Specific to avoiding overheating would be measures aimed at limiting the growth of domestic demand; and specific to preventing financial fragility would be measures implemented to limit over-intermediation, as well as maturity and currency mismatches. See Graph 6 for a diagram of some policy responses to capital inflows.

\footnotetext{
7 Data from J.P. Morgan and author's calculations.
} 


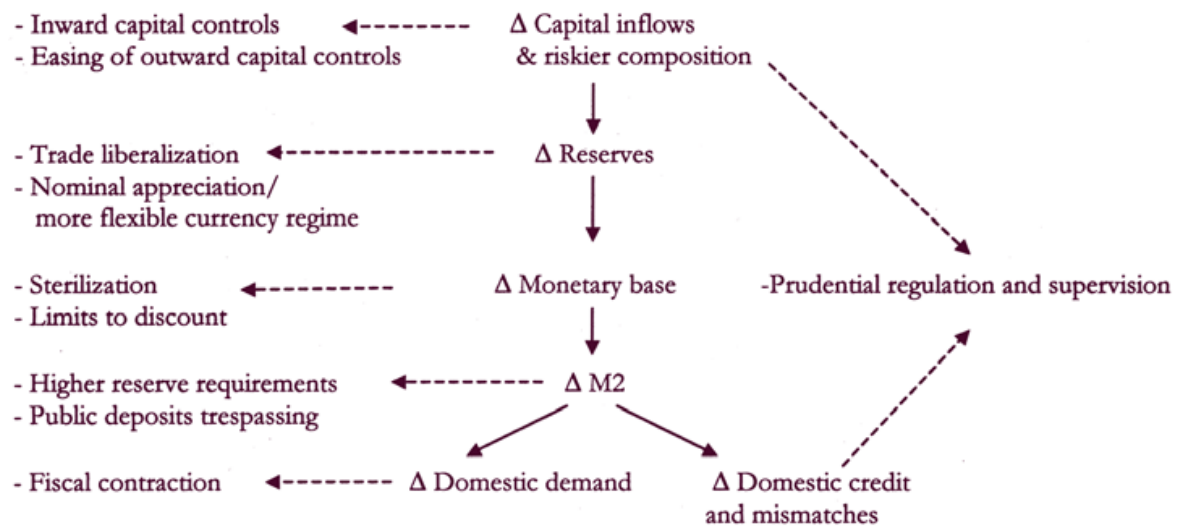

Graph 6. Policies to prevent overheating and financial fragility. ${ }^{\mathrm{a}}$

a The dotted lines indicate the possible policy responses; the solid lines indicate causal relations.

Policies to reduce the net inflow of foreign capital

and/or change its composition

The instruments at hand to achieve a lower net capital inflow are basically restrictions on the entry of capital (inward capital controls) and the ease of restrictions on capital outflows (ease of outward capital controls). The former could also limit the proportion of capital that is volatile and/or denominated in foreign currencies.

Inward capital controls have the obvious advantage that they operate rather mechanically. By reversing the liberalization trend that provoked (or at least permitted) the entry of perilous capital, controls directly limit the original source of overheating and financial fragility. Also, capital inflows are a flexible measure, so that the reversal of liberalization can be temporary and partial. Finally, by reversing or slowing down financial openness, capital inflows can minimize the negative effects of other policies (i.e. sterilization) that do reinforce previous policy trends.

However, capital controls are not a frequent response to capital inflows, probably given the distrust, and lack of support they inspire from the international financial community. Critics frequently argue that controls eliminate the disciplinary effect on economic policy that capital mobility implies, therefore permitting risk-enhancing governmental behaviors. Nevertheless, this argument seems to ignore the mentioned risks imposed by perfect capital mobility. It also neglects the fact that the disciplinary effect may not be so desirable. On the one hand, what international investors consider good economic policy may not be advantageous for the economy. On the other hand, investors' reactions are frequently disproportionate (due to information 
asymmetry), giving oversized 'prizes' and 'punishments' to what they consider 'right' or 'wrong' (Williamson, 1999). In sum, we do not consider that the disciplinary effect of mobility compensates for the risks that capital controls might prevent.

Also, according to critics, capital controls prevent the efficient allocation of financial resources. But controls may bring about a second-best situation, given previous distortions either in the recipient economy or in the way international financial markets operate (Montiel, 1995; Dooley, 1995). An example would be the frequent situation where institutional guarantees - explicit or implicit, real or perceived - distort the allocation of credit. Also, even with no distortion within the domestic financial system, the mere act of borrowing may be distortional, as when capital inflows arise from behaviors not based on the availability or use of information. ${ }^{8}$ In such cases, capital controls would tax foreign indebtedness, causing a more efficient allocation of resources.

In any case, perhaps the most controversial question surrounding capital controls is whether they are effective, given (for instance) difficulties in design or outright evasion. Whether capital controls are effective or not is an empirical issue, and the results of the many studies do not always coincide, because of sampling or methodological differences. Some studies (Johnston and Ryan, 1994) conclude that capital controls are ineffective in insulating the balance of payments or in modifying the composition of capital flows in developing countries. But the voices defending the effectiveness of controls are mounting, ${ }^{9}$ even among the usual proponents of liberalization: evidence from econometric analyses and case studies support the position that inward capital controls can be effective, though their effectiveness may on occasions be limited to the short run, and to altering the structure of capital inflows but not their total amount (therefore limiting financial risks but not overheating).

A not-so-frequent critique of capital controls is that they can trigger suspicions by international investors that the government is abandoning the policy stance which had initially attracted them. Given information asymmetries and the consequent overreactions of investors, the imposition of capital controls could spark a financial panic and perhaps a full-fledged financial crisis. Or, as shown in the empirical study by Chai-anant (2003), FDI could leave in response to controls. This possibility of

8 Dooley (1995) considers that the frequency of these kind of behaviors provides the most compelling argument in favor of capital inflows.

9 Dooley (1995); Grilli and Milesi-Ferretti (1995); Epstein et al. (2003); Montiel and Reinhart (2001); Chai anant (2003). 
overreaction of international investors is perhaps the most serious downside of our recommendation of partially reversing stabilization and liberalization policies. Thus the question arises of how to maintain some sovereignty over capital flows without triggering overreactions.

A second measure to limit the net inflow of capital is to ease restrictions on capital outflows. This policy, unlike inward controls, reinforces financial openness. It can be said to have diverse advantages, such as facilitating the diversification of the residents' portfolios, and possibly increasing the efficiency of the domestic financial market (Bennett et al., 1993; Lee, 1996). But easing restrictions on capital outflows also has important limitations as a measure to prevent trade-related and financial risks, those limitations being related to the fact that it pursues a previous liberalization trend. On the one hand, financial liberalization may have already gone so far that further liberalization is not feasible anymore. On the other hand, this measure is not necessarily effective: by reinforcing confidence and prospects of profitability, it may even attract more gross inflows than it provokes gross outflows, becoming counterproductive. Labán and Larraín (1993) and Bartolini and Drazen (1997) present theoretical models in which eased restrictions on the outflow of capital attract foreign capital, via the reduction of uncertainties over the possibility of repatriating that capital.

Of the three countries considered, Malaysia resorted most decisively to inward capital controls. It did so temporarily, with the aim of curbing the entry of volatile capital. In January and February 1994, authorities established several controls, such as a ceiling on net indebtedness (excluding debts related to trade or FDI), and the prohibition of selling to non-residents monetary instruments with a maturity shorter than a year (ADB, 1995/1996). In August 1994 these measures began to be eliminated, and by the end of 1995 they had all been removed. In Thailand, the only capital control used was the 1990 re-implementation of a tax that had been eliminated in 1988 , consisting of the retention of $10 \%$ of interest payments to foreign lenders. The Indonesian authorities tried to curtail the entry of capital merely by eliminating the system through which they had been hedging the foreign exchange risk of commercial banks, therefore enhancing the risk assumed by those banks (Montiel, 1995; Lee, 1996).

Malaysia's inward capital controls were (at least partially) effective. Graph 1 illustrates how OI - the type of volatile capital entering the country- plummeted when capital controls were imposed and recovered when they were being 
removed..$^{10}$ Nevertheless, at the same time that capital controls were being used, the interest rate differential against the us shrank, due in part to the easing of sterilization efforts, making it difficult to separate the impact of these two actions. But whatever measure worked, it did so by departing from the neoliberal policy stance, via capital controls or monetary relaxation. Controls in the other two countries were not as purposeful as in Malaysia, yielding weaker effects, which were also mixed, in any case, with the impact of interest rates on volatile capital inflows. It would be worth analyzing why capital controls were not used more intensively, the most reasonable assumption being that the explanation is one of political economy (i.e. a lack of support from the international financial community and from certain national groups).

Thailand, Malaysia, and Indonesia had entered the 1990s with an already relatively open financial account. Nevertheless, there remained space for further liberalizing the outflow of capital. Thailand notably liberalized its capital outflows between 1990 and 1994, for instance by eliminating the requirement that the central bank approve the repatriation of capital placed in investment funds. Malaysia further opened its financial account, allowing more capital outflows, roughly between 1988 and 1994, whereas Indonesia, where financial liberalization had advanced notably in the 1980s, intensified capital outflow liberalization around 1994 (ADB, 1995/1996).

Hence, with more or less intensity, the easing of restrictions on the outflow of capital occurred continuously from the beginning of financial liberalization at the end of the 1980s through the first half of the 1990s. As to whether this policy further attracted capital inflows, the aforementioned empirical studies suggest that financial liberalization did act as a pull factor for capital in East Asia. At the very least, this measure did not generate an outflow of funds large enough to compensate for the increasing capital inflows. Indeed, the gross outflow of capital was negligible. In Malaysia there were even several years in the mid-1990s when the sign of the outward oI was positive, indicating the return of capital previously invested abroad.

\section{Policies to restrict the growth of international reserves}

Governments may try to counteract the effects of a surplus in the financial account on international reserves by generating (or broadening) a current account deficit. This could be attempted by deepening trade liberalization, or by resorting to the nominal appreciation of the domestic currency and/or to a more flexible exchange rate regime.

10 Montiel (1999) also shows how capital controls in Malaysia altered both the volume and the composition of capital inflows in the short run. 
In a way, aiming to deteriorate the current account balance might be perceived as absurd when one of the goals of limiting the growth of reserves is precisely to avoid the real appreciation of the domestic currency and its ill effects on the current account balance. Nevertheless, these measures could be considered by policymakers because they at least eliminate the inflationary pressures and financial fragility associated with an increase in the monetary supply.

The further opening of trade presents several downsides related to the fact that it reinforces the liberalization trend that was originally attractive to foreign investors. First, as we argued for the financial account, the current account could already be so open that to resort to trade liberalization becomes impossible.

Second, more openness could feed the country's attractiveness for international investors. On the one hand, simply by enhancing the confidence of investors in the commitment of the government to the 'correct' economic policy; as well as by attracting export-oriented FDI, which would enhance overheating. On the other hand, trade liberalization may be ineffective in limiting the growth of reserves, since its effects on the current account balance are ambiguous. Too many factors interplay to yield a higher or lower current account balance as the result of increased openness, so that the improvement of the current account balance is clearly a possible outcome. Montiel (1995) offers the example of a country where tradable goods are intensive in intermediate and capital goods, and where liberalization especially affects those goods. In such a case — so frequent in developing countries - trade liberalization would lead to higher export competitiveness via access to cheaper intermediate and capital goods. If trade liberalization led to a better current account balance, it would fuel the growth of international reserves, the opposite of what was intended. This growth of reserves could foster the confidence of international investors in a fixed exchange rate, which in turn would attract more capital, particularly of a volatile nature (Reinhart and Reinhart, 1998; Dooley, 1999).

In sum, trade liberalization may be unfeasible. When employed, it may be ineffective and even counterproductive. In any case, trade openness is rarely used as a discretionary policy to counteract the effects of capital inflows, but more as part of wider structural adjustment programs (as the empirical study of Bennett et al., 1993, shows).

Turning to nominal appreciation or to making the currency regime more flexible would imply a departure from the previous fixed currency regime which attracted investors in the first place. This departure, when made via nominal appreciation, 
could bring about the perception that the government's anti-inflationary stance is not solid, since the opposite measure (nominal devaluation) suddenly appears equally possible. This could curb capital inflows. Making the currency regime more flexible could also discourage the inflow of more capital —especially for destabilizing capital (Montiel, 1999; Lee, 1996; Reinhart and Reinhart, 1998). Therefore, these measures could have a double effectiveness: first, by worsening the current account, and second, by limiting the confidence of investors, and therefore curbing risky capital inflows.

Their downsides are considerable, however. It is not advisable to use these measures in a discretionary fashion, since that may impose excessive costs in terms of the reallocation of productive resources in response to changes in the exchange rate (Bennett et al., 1993; Montiel, 1995). Also, these policies could bring about large political costs, as when the fixed regime does not include an escape clause. In fact, nominal appreciations and making the currency regime more flexible are infrequent measures, perhaps precisely because fixed regimes rarely include an explicit escape clause, and the political cost of modifying an exchange rate arrangement is much higher when the reasons for modification have not been determined a priori (UNCTAD, 2001).

Also, making the exchange rate more flexible could, in the extreme, render a close-to-floating exchange rate regime, with all the downsides that this implies: monetary independence is not guaranteed by a floating exchange rate given the 'fear of floating' (Calvo and Reinhart, 2000); a flexible rate may impose more difficulties to fight against inflation; exchange rate volatility imposes trade and debt management difficulties (UNCTAD, 2001); currency flexibility does not necessarily reduce currency and maturity mismatches, given the 'original $\sin ; ;{ }^{11}$ and it does not eliminate the possibility of suffering a financial crisis, via the self-fulfillment of devaluation or default expectations.

As with capital controls, the fact that these measures alter the previous policy position impose a risk of disruptive reversal in capital flows, given information asymmetries and the consequent overreactions of investors. This makes it advisable for developing countries to employ pegged but flexible regimes (what are sometimes

11 The original sin stems from the fact that developing countries' currencies lack credibility, so that the capital which international investors are willing to lend to those countries is short term and denominated in foreign currencies. Hence, the original sin hypothesis argues that currency and maturity mismatches are the consequence of a lack of credibility more than the result of moral hazard (as has been frequently hypothesized). 
called 'intermediate regimes'), which would allow them to manage the exchange rate in the face of capital inflows. With a transparent intermediate regime governments could resort to nominal appreciation without fearing investors' overreaction.

In Thailand, Malaysia, and (to a lesser extent) Indonesia, the current account had traditionally been more open than in other developing countries (Sachs and Warner, 1995). Still, in the late 1980s and early 1990s there was room for further trade liberalization. But this further opening in Asia-3 cannot easily be interpreted as a policy to deteriorate the current account, given that it was part of a broader policy package to promote export orientation, introduced or reinforced around the turn of the decade (Felker and Jomo, 1999).

Imports did react to growing openness, increasing in 1987-1996. But, in response to export orientation, exports also grew, limiting the effects of liberalization on the current account balance. Furthermore, the deterioration of the current account balance which occurred in the years immediately before the crises is attributable more to the real appreciation of the currency and factors external to Asia-3 than to the mere opening of the current account.

These countries barely resorted to nominal appreciation or to making their currency regimes more flexible. Thailand had, since 1985 and until 1997, a fixed exchange rate against a basket of currencies. Malaysia and Indonesia had, de jure, more flexible regimes: Malaysia had a fixed regime in 1990-92, and then turned to controlled flotation; Indonesia had maintained since the mid-1980s a controlled flotation within a band, and a devaluation trend in pace with the inflation differential against the US. But even in Malaysia and Indonesia the stability of the currency was de facto defended. ${ }^{12}$ In Indonesia, even in those years when the flotation band was widened, this was not intended to generate a significant appreciation of the rupee, since measures to maintain its value were used. Furthermore, the dollar had a dominant weight in the rates defended, even when the parity was officially against a basket of currencies (Ohno, 1999). Table 2 shows the stability of these countries' currencies against the dollar and the absence of considerable nominal appreciations.

In summary, more flexible currency regimes and/or nominal appreciations were scarcely used. Again, it is not easy to determine why these countries did not choose these measures, the most reasonable hypothesis being the lack of sufficient flexibility

12 Calvo and Reinhart (2000) argue in favor of the existence of 'fear of floating' in developing countries, as do Hernandez and Montiel (2001) for the cases here studied. 


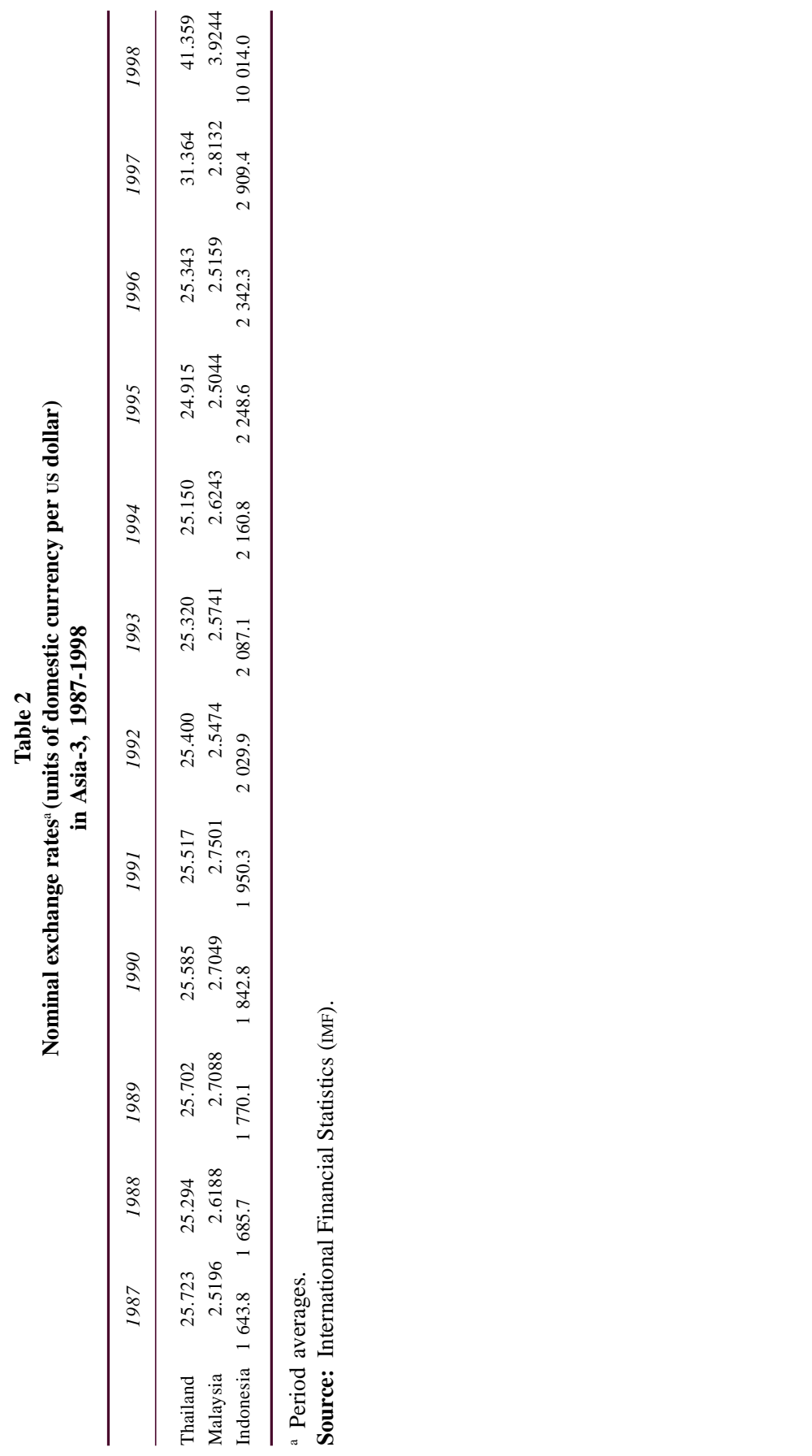


in their currency regimes, as well as the export orientation of their industrialization paths: "monetary authorities in Asian countries, which enjoyed low and stable inflation rates, were $[\ldots]$ concerned about economic competitiveness, thus keeping their respective nominal exchange rates stable" (Shen and Wang, 2001). Even now, these countries maintain intermediate regimes (Malaysia and Indonesia have managed floats, as they did prior to the crisis, while Thailand has moved from a peg to a managed float), precisely to aid development through trade expansion (Cohen, 2006).

Policies to restrict the growth of the monetary base

Sterilization, narrowly defined, is an exchange of bonds for foreign currency: the government purchases foreign currency to avoid excess demand for national currency, and it simultaneously issues bonds to eliminate the impact of growing reserves on the monetary base. Sterilization is very common as a response to capital inflows. Being a flexible measure, it gains time while the specific features of capital inflows are evaluated (Calvo, 1990; Bennett et al., 1993; Montiel, 1995 and 1999).

However, sterilization presents two important downsides, which arise when it is preceded by liberalization and stabilization measures. First, it may not be effective, as a result of financial openness. Second, when (partially or totally) effective, it may turn counterproductive, as a result of the success in reinforcing monetary constraints.

Given capital mobility and a fixed exchange rate, sterilization may be ineffective. According to the Mundell-Fleming model (Mundell, 1963), it is not possible for monetary independence, perfect capital mobility and a fixed exchange rate to coexist. When two of those elements are present, the third becomes unsustainable. Sterilization, as a form of restrictive monetary policy, brings about higher interest rates (or at least a higher interest rate differential than otherwise), ${ }^{13}$ which, in turn and by virtue of capital mobility, attract more foreign capital. These new inflows of capital offset the impact of sterilization on the interest rates, rendering it ineffective. Of course, capital mobility might be imperfect, in which case sterilization could be partially effective.

13 Even when sterilization does not imply an outright increase in interest rates, it at least counteracts the downward pressure derived from capital inflows. Therefore, sterilization would always bring about a higher interest rate differential than that which would prevail without sterilization. 
When sterilization results in a higher interest rate than otherwise - that is, when sterilization is effective- it may turn counterproductive. On the one hand, the additional capital inflows further enhance the risk of overheating and/or financial fragility. On the other hand, the additional capital inflows are likely to be composed mostly of volatile capital (the kind most attracted by higher interest rate differentials), consequently feeding financial fragility.

Limiting the access to rediscounting at the central bank is another measure aimed at restricting the growth of the monetary base. It is not as flexible as sterilization, especially in those countries where the rediscount rate is used as a means to provide cheap credit to priority sectors. Also, the weakness of the link between the rediscount rate and other interest rates makes it a not very effective tool for controlling credit growth (Lee, 1996). Finally, if there were, in fact, a transmission from discount rates to other interest rates, this measure could turn counterproductive, just like sterilization, via the attraction of further volatile foreign capital.

Sterilization was used throughout Asia-3 soon after the beginning of the capital inflow episode and for several more years. Thailand sold bonds between 1987 and 1995, Malaysia between 1989 and 1993, and Indonesia mostly in 1990-1993 and 1996 (Seng and Villanueva, 1999). These countries also resorted to raising the rediscount rate: Thailand in 1990, 1994 and 1995; Malaysia in 1988-1991 and 1995-1996; and Indonesia in 1990 and 1994-1995.

Capital mobility was not so perfect as to prevent these measures from working. Interest rate differentials did respond to sterilization (Furman and Stiglitz, 1998). The econometric study by Esaka and Takagi (2001) posits that sterilization did not bring about higher money market interest rates, but that it is likely that at least it kept interest rates above the level to which they would have fallen with closer-toperfect capital mobility. Finally, the maintenance of relatively high interest rate differentials attracted additional capital inflows, mostly loans: when sterilization was relaxed and interest rate differentials fell, the inflows of OI were lower. ${ }^{14}$ In sum, the growth of reserves did not translate into a proportional increase in the monetary base, thanks to the effectiveness of sterilization. But this effectiveness was only partial, in view of the growth of the monetary base during the capital inflow episode, and the higher and more volatile capital inflows.

14 See econometric evidence in Montiel and Reinhart (2001), and Esaka and Takagi (2001). 
Policies to limit the growth of M2

Reserve requirements aim at immobilizing a higher proportion of financial institutions' liabilities, so that the growth of the monetary base does not transform itself into credit growth. As sterilization, this is a flexible measure: the raising of reserve requirements is a faster measure than correctly pricing those institutional guarantees which foster over-intermediation. Another tool for avoiding credit growth is to shift public funds from commercial banks to the central bank.

These measures and other forms of credit control somehow reverse the trend toward financial deregulation, the original attraction for investors. At the same time, if focused on preventing the growth of certain types of credit, they can be useful tools for preventing financial fragilities. Hence, these measures could have a double effectiveness: by discouraging further capital inflows, and, most of all, by preventing these from being intermediated in a risky manner.

But the downsides are also notable, mostly because these measures, when used in a discretionary fashion, make it more difficult for banks to manage their portfolios, thus enhancing financial fragility. Also - and this may be the most frequent critique - reserve requirements can be ineffective via disintermediation (Lee, 1996; Spiegel, 1995). Disintermediation not only makes reserve requirements ineffective but also open the door to higher financial fragility, given that NBFIs are usually less strictly regulated and supervised than banks. Nevertheless, financial regulation in general has proven to be effective (Rossi, 1999).

As indicated for capital controls and nominal appreciations, the fact that these measures reverse the trend toward deregulation could imply a risk of sudden and disruptive reversal of capital inflows. Nevertheless, the international consensus on the need for prudential regulation is much stronger than on capital controls or exchange regime choice, making overreaction of investors less likely.

Thailand used several measures aimed at limiting credit growth. It increased reserve requirements in 1995 and 1996. Also, indicative and direct controls on bank credit were imposed or reinforced. For instance, the Bank of Thailand imposed ceilings on the banks' ratio of loans to deposits, and limits on bank loans for unproductive activities were established. In Malaysia, the economic authorities increased reserve requirements and extended them to non-residents' deposits and other forms of foreign capital, especially in 1989-1992 and 1994-1996. Also, they restricted the access of credit cards and credit for the purchase of certain products, such as motor vehicles. Indonesia barely resorted to increased reserve requirements, 
and most credit control took place through moral suasion. The authorities of these three countries also shifted public deposits to the central banks. The most significant case was that of Malaysia, where in 1992 the Employee Provident Fund (more than \$2.6 billion) was put into Bank Negara Malaysia (on all these policies, see Corbo and Hernandez 1994, Lee, 1996, Alba et al., 1998, and Seng and Villanueva, 1999).

Given the steady growth of M2 during the decade prior to the 1997 crises, it seems that these measures were not effective enough. The increase in reserve requirements and other forms of credit control can be considered part of prudential regulation; and, as we shall see, prudential regulation, in general, was strengthening but insufficient in all three countries.

\section{Policies to limit the growth of domestic demand}

Up to this point we have reviewed policies that could act against the surge of both overheating and financial fragility. Here we focus on a policy aimed specifically at limiting overheating: fiscal contraction. The effectiveness of fiscal contraction is quite assured, since it acts mechanically on domestic demand; and it does so regardless of the causes of capital inflows, the degree of financial opening, or the prevailing exchange rate regime (Corbo and Hernandez, 1994). There is empirical evidence on the effectiveness of a restrictive fiscal policy (World Bank, 1997).

The downsides of this measure are notable. First, by reinforcing budgetary prudence, fiscal restriction feeds the confidence of international investors about the anti-inflationary stance of the government. Furthermore, if fiscal contraction had already been such as to balance public budgets, it becomes difficult to turn to it, both for technical and political reasons. Second, fiscal restriction as a response to capital inflows implies substituting public expenditure for consumption, investment, and/or imports, all financed with the incoming capital. This alteration of the composition of aggregate demand is not a problem per se. But it becomes one when certain public investments, such as in infrastructure or human capital, are much needed. It is also problematic when private agents use foreign capital in a non productive way (as occurs when capital inflows are directed to consumption, overinvestment in productive assets, or investment in real estate or financial assets some of which, as seen above, are likely to happen in the face of massive capital inflows).

Perhaps for all these reasons, fiscal contraction is rarely the main response to capital inflows. Furthermore, fiscal contraction, as trade liberalization, is usually 
more closely linked to wider structural adjustment programs than to discretionary policy (Bennett et al., 1993; Montiel, 1999).

Asia-3 had already been pursuing a prudent fiscal stance since the mid 1980s, mostly as part of a wider adjustment package. But, beginning around 1995, fiscal policy became either slightly expansionary or less restrictive (World Bank, 1998; Alba et al., 1998). In Thailand, fiscal policy became expansionary in 1994. In Malaysia and Indonesia fiscal policy did not turn expansionary, but it became less restrictive around 1995. Therefore, these countries did not use discretionary fiscal contraction, and even less so in the years preceding 1997. Given their fiscal health, there was not much room for restriction. Also, the long-run goals of these countries (i.e. moving upward on the technological scale) relied on public investment in secondary education and infrastructure (Stiglitz, 1999; Felker and Jomo, 1999). ${ }^{15}$

Policies to restrict over-intermediation

and currency and maturity mismatches

According to the mentioned theories about financial risks as effects of capital inflows, the circumstances under which these arise are: the lack of prudential regulation and supervision, the presence of institutional guarantees, and uncertainty. Therefore, correcting any of these circumstances could help eliminate the impact of capital inflows on the health of the domestic financial system. Nevertheless, great difficulties arise in tackling the last two of these circumstances. Institutional guarantees are difficult to remove. Even when the most obvious guarantees are eliminated, others may persist, such as when there is a fixed exchange rate regime (Dooley, 1999). Furthermore, even if all guarantees were in fact removed, the mere perception of their existence could boost excessive risk-taking. Additionally, if the original sin is indeed a more powerful explanation of financial risks than moral hazard, the elimination of guarantees is not enough to prevent risks. Regarding uncertainty, it can be argued that this is an inherent feature of capital markets, and even more so if the markets are international (Hermalin and Rose, 1999). Thus, there is little that governments can do to eliminate it.

Hence, we focus on financial regulation and supervision. ${ }^{16}$ These measures imply a departure from the policy stance that acts as a pull factor for perilous capital

15 Fiscal restriction (brought about by the IMF rescue packages), which has been widely criticized, did occur after the crises (Woo, 2000).

16 Prudential regulatory measures and capital controls cannot be separated neatly. The blurriness of the division is leading some authors (Epstein et al., 2003) to analyze 'capital management 
inflows: re-regulation counteracts the deregulation of financial liberalization, even if the new regulations are of a different nature — 'prudential' instead of 'economic'. Also, regulation and supervision seem to be effective, according to empirical studies, even when imperfect (Rossi, 1999).

Maybe the best known instrument of external regulation is the capital adequacy ratio, designed by the BIS. Though highly recommendable, this measure is no panacea (Garber, 1996). Consequently, other external measures are also necessary: limits to internal credit, which would be particularly useful if imposed on credit extended for consumption, or for risky sectors, and if they were directed to avoid an excessive concentration of credit; restrictions on the total external indebtedness of banks, or on the proportion of liabilities denominated in foreign currencies and/or of a short-term nature; measures to limit the problems imposed by too-big-to-fail financial institutions; etc.

Generally speaking there are some obstacles to external regulation, many of which could be more serious in developing countries: the usual lack of transparency of financial markets; the scarcity of human, technical, and financial resources to implement regulation and supervision; incentives for public authorities to indulge in regulatory forbearance; and incentives for bank owners and managers to take too many risks. Also, the complexity and interdependence of the many elements that compose effective regulatory systems make it particularly difficult for developing countries to design and implement them. Complementary measures are usually recommended in order to dodge some of these problems, as well as to trespass (shift) part of the supervisory responsibility to the market itself.

Overall, the most serious downside of regulation is that, given political, social, and institutional rigidities, the design and implementation of a good regulatory and supervisory system takes time - much more time than it takes to open the financial account and receive massive capital inflows.

In Asia-3, some steps were taken during the 1980s in re-regulating their rapidly changing financial systems. For instance, in Thailand, the Commercial Banking Act of 1979 introduced the first formal controls over financial companies, and the central bank was given further power as a supervisory agency. In Malaysia, the BPI capital adequacy ratio was introduced in 1988, and Bank Negara Malaysia was given supervisory and punitive powers. In Indonesia, in the late 1980s, some

techniques' instead of looking at capital controls and prudential regulation separately. Also, it should be noted that the regulation to which we refer in this section is not what is sometimes called 'economic regulation' (that is, regulation aimed at intervening in markets) but 'prudential regulation' (that is, regulation aimed at restricting financial fragility). 
restrictions on credit were introduced, the supervisory department of the central bank was reorganized and expanded, and the Bank Indonesia Supervisory Monitory System was established to advise on banking practices. ${ }^{17}$

In any case, financial regulation and supervision were far from being sufficiently responsive to capital inflows. In the years prior to the crises, prudential regulation and supervision in Asia-3 was below even those standards achieved by other Asian or Latin American countries. Caprio (1998) developed a regulation and supervision index and applied it to 12 Asian and Latin American countries. The study concluded that Singapore ranked best with an index of 16 (the lower the index, the better the regulatory and supervisory system). At the other extreme were Malaysia (41), Colombia (44), South Korea (45), the Philippines (47), Thailand (52), and Indonesia (52).

In all three countries, first, capital adequacy ratios were not enforced effectively. Second, rules about credit classification and required provisions were too indulgent. Third, the absence of accountancy standards made supervision more difficult, opening the door to evasion. Fourth, the public agencies in charge of regulation and supervision were slow or reluctant to react. Fifth, regulation and supervision for NBFIS were less strict than for banks, in spite of their growing presence (Llewellyn, 2000). There were, of course, differences among the three countries studied, the efforts undertaken by Malaysia being especially notable, though still insufficient. ${ }^{18}$

\section{Concluding remarks}

In this paper we have outlined how overheating and financial risks can arise from the entry of massive foreign capital — particularly capital denominated in foreign currencies and of a volatile nature. We have also gone over the cases of Thailand, Malaysia, and Indonesia. Next, we have reviewed the theoretical/logical downsides of many of the possible policy responses to capital inflows, as well as the use and results of these in Thailand, Malaysia, and Indonesia. We have done so under the unifying lens of whether each policy alternative reinforced the stabilization and liberalization stance that had fostered perilous capital inflows.

Generally speaking, policies that reinforce a previous stabilization and liberalization package risk feeding the confidence of international investors and therefore attracting

17 See details in Bank of Japan (1990).

18 For obvious reasons, regulation and supervision have been strengthened after the crises in all three countries (see Batunanggar, 2002, for the case of Indonesia). Still, proposals exist for instituting a regional system of financial surveillance (Poonpatpibul et al., 2006). 
further risky capital. Thailand, Malaysia, and Indonesia resorted to various policies in order to prevent the potential ill consequences of massive capital inflows. These capital inflows had been the result, inter alia, of stabilization and liberalization policies implemented in the 1980s (García, 2005). Still, many of the policy responses reinforced those initial measures.

- Regarding fiscal policies, fiscal restriction was not intensively used, probably because of the difficulty in resorting to contraction in a context of healthy public budgets, and given the needs of Asia-3 in infrastructure and education.

- Regarding monetary policies, restriction was exerted mostly via sterilization, which was used for several years beyond the advent of capital inflows. The monetary stance which had been set in the 1980s was thus reinforced. This reinforcement attracted further volatile capital inflows and was, therefore, only partially effective and even counterproductive.

- Currency-related policies (nominal appreciation or a more flexible currency regime) were barely used, maintaining the currency regimes set in the mid- or late-1980s. It seems that the absence of flexibility in their currency regimes and the export-oriented growth strategies of these economies contributed to this decision.

- Trade liberalization was strengthened in the 1990s. This measure was probably not implemented with the aim of worsening the current account balance, nor was it very effective in achieving that goal: exports grew at almost the same pace as imports. Also, this measure reinforced the trend set prior to the massive inflow of capital, feeding investor confidence.

- Nor was the financial opening reversed, inward capital controls being used only briefly. Again, the trend set in the 1980s was maintained. It is not easy to determine why these governments did not use capital controls more intensively. The main reason could be the clear bias against them prevailing among international investors and international financial institutions.

- Regulations to substitute those being removed by the process of financial deregulation were insufficient, both at the beginning of deregulation and in the face of capital inflows. Probably, these measures were not implemented more decisively because re-regulation of a financial system requires institutional change.

In Asia-3 the policies that reinforced stabilization and liberalization (principally, sterilization and further trade and financial openness) were indeed ineffective or 
even counterproductive. Policies that depart from the policy stance that attracted capital inflows were barely tried (capital controls, a more flexible currency regime) or were implemented too slowly (prudential regulation and supervision).

Those measures that depart from stabilization or liberalization face obstacles to implementation: prudential regulation and supervision demand institutional change, and hence time, whereas capital controls and an active management of the currency may face the distrust and overreactions of international financial agents. Further research is needed to understand whether such reasons explain their scarce use in Asia-3. In general, more research is needed on how to promote a more frequent or rapid implementation of these measures —and how to minimize investors' overreactions.

\section{References}

ADB, Asian Development Outlook 1995 and 1996, NewYork, Oxford University Press, 1995/1996.

Alba, P., A. Bhattacharya, S. Claessens, S. Ghosh and L. Hernández, "Volatility and Contagion in a Financially Integrated World: Lessons from East Asia's Recent Experience", Policy Research Working Paper WPS 2008, World Bank, November 1998.

Bank of Japan, "Financial Reform in Asian Economies", Special Paper n. 189, Research and Statistics Department, Bank of Japan, May 1990.

Bartolini, L. and A. Drazen: "Capital Account Liberalization as a Signal", Working Paper 5725, National Bureau of Economic Research, July 1997.

Batunanggar, S., "Indonesia's Banking Crisis Resolution. Lessons and the Way Forward", presented at the Banking Crisis Resolution Conference, Bank of England, 9December 2002.

Bennett, A., M. Carkovic, R. Kahn and S. Schadler, "Recent Experiences with Surges in Capital Inflows", Occasional Paper 108, IMF, December 1993.

Bustelo, P., C. García and I. Olivié, Crisis financieras en economías emergentes: enseñanzas de Asia oriental, Madrid, Ediciones Cooperación al Desarrollo, Agencia Espa-ñola de Cooperación Internacional, 2000.

Calvo, G.A., "The Perils of Sterilization", Working Paper 90/13, IMF, March 1990.
Calvo, G.A. and C.M. Reinhart, "Fear of Floating", Working Paper 7993, National Bureau of Economic Research, November 2000.

Caprio, G. Jr., "Banking on Crises: Expensive Lessons from Recent Financial Crises", Policy Research Working Paper wPs 1979, World Bank, September 1998.

Chai-Anant, C., "Effects of Policies on Capital Flows to Emerging Markets: Evidence from a Detailed Data Set", Discussion Paper 05/ 2003, Bank of Thailand, October 2003.

Chang, R. and A. Velasco, "Financial Crises in Emerging Markets: A Canonical Model", Working Paper 98-10, Federal Reserve Bank of Atlanta, July 1998.

Chuhan, P., S. Claessens and N. Mamingi, "Equity and Bond Flows to Latin America and Asia: The Role of Global and Country Factors", Policy Research Working Paper wPS 1160, World Bank, July 1993.

Cohen, B.J., "After the Fall: East Asian Exchange Rates since the Crisis", presented at East Asia: A Decade after the Crisis, Canberra, Australia, July 2006.

Connolly, M.B. and D. Taylor, "The Exact Timing of the Collapse of an Exchange Rate Regime and Its Impact on the Relative Price of Traded Goods", Journal of Money, Credit and Banking, 16(2), May 1984, pp. 194-207.

Corbo, V. and L. Hernandez, "Macroeconomic Adjustment to Capital Inflows: Latin 
American Style versus East Asian Style", Policy Research Working Paper wPS 1377, World Bank, 1994.

Corsetti, G., P. Pesenti and N. Roubini, "What Caused the Asian Currency and Financial Crisis?", Working Papers 6833 and 6834, National Bureau of Economic Research, December 1998

Disyatat, P., R. Pongsaparn and A. Waiquamdee, "Effective Exchange Rates and Monetary Policy. The Thai Experience", Discussion Paper 04/2005, Bank of Thailand, May 2005.

Dooley, M.P.: "A Survey on Academic Literature on Controls over International Capital Transactions", Working Paper 5352, National Bureau of Economic Research, November 1995

, "A Model of Crises in Emerging Markets", Working Paper 6300, National Bureau of Economic Research, December 1997.

, "Are Capital Inflows to Developing Countries a Vote for or against Economic Policy Reforms?", in P.R. Agénor, M. Miller, D. Vines and A. Weber (editors), The Asian Financial Crisis. Causes, Contagion and Consequences, Cambridge, Cambridge University Press, 1999, pp. 112-123.

Eichengreen, B. and R. Hausmann, "Exchange Rates and Financial Fragility", Working Paper 7418, National Bureau of Economic Research, November 1999.

Epstein, G., I. Grabel and K.S. Jomo, "Capital Management Techniques in Developing Countries: An Assessment of Experiences from the 1990's and Lessons for the Future", Working Paper 56, Political Economy Research Institute, University of Massachusetts Amherst, April 2003.

Esaka, T. and S. Takagi, "Sterilization and the Capital Inflow Problem in East Asia, 19871997”, in T. Ito and A.O. Krueger (editors), Regional and Global Capital Flows: Macroeconomic Causes and Consequences, Chicago, Illinois, University of Chicago Press, 2001, pp. 197-226.

Felker, G. and K.S. Jomo, "New Approaches to investment Policies in ASEAN 4", presented at $2^{\text {nd }}$ Annual Conference, Asian Development Bank Institute, December 1999.

Fernandez-Arias, E., "The New Wave of Private Capital Inflows: Push or Pull?", Journal of Development Economics, 48(2), March 1996, pp. 389-418.
Furman, J. and J.E. Stiglitz, "Economic Crises: Evidence and Insights from East Asia", Brookings Papers on Economic Activity, $\mathrm{n}$. 2, 1998, pp. 1-135.

Garber, P.M., "Managing Risks to Financial Markets from Volatile Capital Flows: the Role of Prudential Regulation", International Journal of Finance and Economics, 1(3), July 1996, pp. 183-195.

García, C., Capital extranjero y política económica. Las crisis financieras del sudeste asiático, Editorial Fundamentos, Madrid, 2005.

Goldstein, M., "Coping with too much of a Good Thing: Policy Responses for Large Capital Inflows to Developing Countries", Policy Research Working Paper wPS 1507, World Bank, 1995.

Hermalin, B.E. and A.K. Rose, "Risks to Lenders and Borrowers in International Capital Markets", Working Paper 6886, National Bureau of Economic Research, January 1999.

Hernandez, L. and P.J. Montiel, "Post-Crisis Exchange Rate Policy in Five Asian Countries: Filling in the 'Hollow Middle'?", presented at High Level Seminar: Exchange Rate Regimes. Hard Peg or Free Floating, International Monetary Fund Institute, Washington, DC, March 19-20 2001.

IMF, World Economic Outlook. May 1999, Washington, DC, International Monetary Fund, 1999.

Johnston, R.B. and C. Ryan, "The Impact of Controls on Capital Movements on the Private Capital Accounts of Countries' Balance of Payments: Empirical Estimates and Policy Implications", Working Paper 94/ 78, IMF, July 1994.

Krugman, P., "What Happened to Asia?", Massachusetts Institute of Technology, mimeo, 1998.

Labán, R. and F.B. Larraín, "Can a Liberalization of Capital Outflows Increase Net Capital Inflows?", Working Paper 155, Instituto de Economía, Pontificia Universidad Católica de Chile, 1993.

Lee, J.Y., "Implications of a Surge in Capital Inflows: Available Tools and Consequences for the Conduct of Monetary Policy", Working Paper 96/53, IMF, May 1996.

Llewellyn, D.T., "Some Lessons for Bank Regulation from Recent Crises", Staff Report 51, De Nederlandsche Bank, 2000. 
Mckinnon, R.I. and H. Pill, “Credible Economic Liberalizations and Overborrowing", The American Economic Review, 87(2), May 1997, pp. 189-203.

Mishkin, F.S., "International Capital Movements, Financial Volatility and Financial Instability", Working Paper 6390, National Bureau of Economic Research, January 1998.

Montiel, P.J., "Managing Economic Policy in the Face of Large Capital Inflows: What Have We Learned?", presented at Private Capital Flows to Emerging Markets after the Mexican Crisis, Institute for International Economics, Osterreichische Nationalbank, Viena, September 7-9 1995.

, "Policy Responses to Volatile Capital Flows", presented at Capital Flows, Financial Crises, and Policies, World Bank, Washington, DC, April 15-16 1999.

Montiel, P.J. and C.M. Reinhart: "The Dynamics of Capital Movements to Emerging Economies during the 1990s", in S. GriffithJones, M.F. Montes and A. Nasution (editors), Short-Term Capital Flows and Economic Crises, New York, Oxford University Press, 2001, pp. 3-28.

Mundell, R.A., "Capital Mobility and Stabilization Policy under Fixed and Flexible Exchange Rates", The Canadian Journal of Economics and Political Science, 29(4), November 1963, pp. 475-485.

Obstfeld, M., "The Logic of Currency Crises", Working Paper n. 4640, National Bureau of Economic Research, September 1994.

Ohno, K., "Exchange Rate Management in Developing Asia. Reassessment of the PreCrisis Soft Dollar Zone", Working Paper 1, Asian Development Bank Institute, January 1999.

Poonpatpibul, C., S. Tanboon and P. Leelapornchai, "The Role of Financial Integration in East Asia in Promoting Regional Growth and Stability", presented at вот Symposium, Bank of Thailand, August 2006.

Radelet, S. and J.D. Sachs, "The Onset of the East Asian Financial Crisis", Working Paper 6680, National Bureau of Economic Research, August 1998.

Reinhart, C.M. and V.R. Reinhart, "Some Lessons for Policy Makers Who Deal with the Mixed Blessing of Capital Inflows", in M. Kahler (editor): Capital Flows and Financial Crises, Ithaca, New York, Cornell University Press, 1998, pp. 93-127.
Rossi, M., "Financial Fragility and Economic Performance in Developing Economies: Do Capital Controls, Prudential Regulation and Supervision Matter?", Working Paper 99/ 66, IMF, May 1999.

Sachs, J.D. and A. Warner: "Economic Reform and the Process of Global Integration", Brookings Papers on Economic Activity, n. 1 ( $25^{\circ}$ anniversary edition), 1995, pp. 1-95.

Sarno, L. and M.P. Taylor, "Capital Flows to Developing Countries: Long-and Short-Term Determinants", The World Bank Economic Review, 11(3), September 1997, pp. 451-470.

Seng, L.C. and D.P. Villanueva, "Managing Capital Flows in SEACEN Countries, A Policy Agenda", presented at Managing Capital Flows in a Volatile Financial Environment, EDI-CPBMES, Bangkok, February 1999.

Shen, C.H and L.R. Wang, "To Intervene or not to Internvene. Exchange Rate Responses to Capital Flows in Selected Asian Economies", ASEAN Economic Bulletin, 18(1), April 2001,pp. 63-82.

Spiegel, M.M., "Sterilization of Capital Inflows through the Banking Sector: Evidence from Asia", Federal Reserve Bank of San Francisco Economic Review, n. 3, 1995, pp. 17-34.

Stiglitz, J.E., "Lessons from East Asia", Journal of Policy Modelling, 21(3), May 1999, pp. 311-330.

Tang, M. and J. Villafuerte, "Capital Flows to Asian and Pacific Developing Countries: Recent Trends and Future Prospects", Statistical Report Series 18, Economics and Development Resource Center, Asian Development Bank, November 1995.

UNCTAD, Trade and Development Report, 2001, New York and Geneva, UNCTAD, 2001.

Wade, R., "From Miracle to Meltdown: Vulnerabilities, Moral Hazard, Panic, and Debt Deflation in the Asian Crisis", Russel Sage Foundation, mimeo, June 1998.

Williamson, J., "Comments and Discussion on Cooper, 'Should Capital Controls Be Banished?", Brookings Papers on Economic Activity, n. 1, 1999, pp. 130-138.

Woo, W.T., "The Asian Financial Crisis. Hindsight, Insight, Foresight", ASEAN Economic Bulletin, 17(2), August 2000, pp. 113-119.

World Bank, Private Capital Flows to Developing Countries. The Road to Financial Integration, A World Bank Policy Research Report, New York, Oxford University Press, 1997.

, East Asia: The Road to Recovery, Washington, DC, World Bank, 1998. 